- 1967c, read Eleven Kaguru Tales. African Studies, xxvi. 3-36.

- 1967d, read 1968. Eight Kaguru Tales: a Contribution toward a Survey of Kaguru Folklore and Cosmology. Anthropos, lxii. 69-93.

Horner, R. P., read Gaume (ed.). Voyage à la côte orientale de l'A frique pendant l'année I 866 par le R. P. Horner, Gaume, Paris.

Paulssen, F. 1882, read 1922.

Schneider, G. 1788, read 1877 .

Velten, C. (ed.) r 901 . Safari za Wasuaheli; Schilderungen der Suaheli. Both a Swahili and German edition exist, with the same publisher and date of publication: Vandenhoeck und Rupprecht, Göttingen. This contains the following essays relevant to the area (pagination from the German edition):

Mwenyi Hamisi esh-Shirazi, Meine Reise ins Innere Ostafrikas bis zum Tanganyika, pp. I-5s.

Selim bin Abakari, Meine Reise nach dem Nyassen mit der Dampferexpedition des Herrn Major von Wissmann, pp. 56-115; Meine Reise nach Europa von Daressalam bis Berlin, pp. I $16-37$.

Mtoro bin Mwenyi Bakari, Meine Reise nach Udoe bis Uzigua sowie Geschichtliches über die Wadoe und Sitten und Gebräuchen der Wazaramu zusammengestellt, pp. 22 s76.

Abdallah bin Rashid, Meine Reise durch Afrika vom Indischen bis zum Atlantischen Ozean als Teilnehmer der Expedition des Herrn Graf von Goetzen, pp. 198-224.

(All of the above contain useful comments on Zaramo, Zigula, Kwere, etc.)

Winter, E. H., and Beidelman, T. O., n.d. read I968. Tanganyika, pp. 57-204, in Contemporary Changes in Traditional Societies (ed. J. H. Steward), vol. i, University of Illinois Press, Urbana.

\title{
Addenda
}

Bauer, R. P. 1882. Voyage dans l'Oudoé et l'Ouzigoua (Zanguebar), Lyon. (Not available.)

Bauer, R. P., and LeRoy, R. P. 1886. A travexs le Zanguebar: voyage dans l'Oudoé, l'Ouzigoua, l'Oukwere et l'Ousagara (I880-82), Mame, Tours. (Not available; probably another version of the preceding item.)

Beidelman, T. O. 1968. A Case of Kaguru Oral History. Baessler-Archiv, 16, pp. 357-71.

- 1969. Myth, Legend and Oral History: a Kaguru Traditional Text. Anthropos: forthcoming.

Bennett, N. 1963. The Holy Ghost Mission in East Africa 1858-1890, pp. 54-75, in Studies in East African History (ed. N. Bennett), Boston University Press, Boston. (A useful survey, bibliographic sources.)

Courmant, Mgr de. I889. Lettre de Mgr de Courmant. Annales de la Propagation de la Foi, lxi. 47-63. (Very useful comments on all of the early Roman Catholic mission stations; a few comments on Ungulu (Mhonda, Mandera); on missions in Uzaramo (Bagamoyo); Uluguru (Morogoro); Usagara (Kondoa, Ilonga); Ukami (Tununguo).)

Gaume (ed.) I 872 . Voyage à la côte orientale de l'A Arique pendant l'année 1866 par le R. P. Horner. Gaume, Paris. (Unseen; French version of next item in bibliography.)

1873. Reisen in Zanguebar in den Jahren 1867 und 1879 von Pater Horner herausgegeben von Dr. Gaume. Manz, Regensberg. (Not available; most likely a German version of the French edition also edited by Gaume.)

Karst, R. P. 1912. Lettre du R. P. Karst. Annales de la Propagation de la Foi, lxxxvi. 47-63. (Very useful comments on early conditions in Morogoro mission and town; on Luguru-Arab-German relations.)

Kenyon, E. R. 1909. Missions in Eastern Equatorial Africa. The East and the West: Quarterly 
Review for the Study of Missionary Problems, vii. 323-43. (Society for Propagation of the Gospel in Foreign Parts, London.) (Some general information.)

LeRoy, R. P. 1884. Lettre du R. P. LeRoy. Annales de la Propagation de la Foi, lvi. 42-59. (Useful comments on the founding of the first mission station at Bagamoyo; a few comments on the Zaramo.)

Mtey, R. I968. Mila na jadi za Wakaguru. Nchiyetu, xlviii (January), pp. 6-8. (Useful, especially on children's games.)

Rees, D. J., and Doulton, E. W. 1914. Mission Work in German East Africa. Church Missionary Revien, lxv (September), pp. $544-53$. (Essential information on early missionary activities in Ukaguru, Ungulu, and Ugogo; much useful information on early social change, on Islam in Ungulu (Bokwa); valuable map of mission operations in this area.)

Velten, C. (ed.). 1907. Prosa und Poesie der Suaheli. Private Press, Berlin. Unseen; said to contain two pertinent items:

Anonymous: Habari ya Safari ya Uzarumu Madimula, pp. $235-40$.

Anonymous: Habari ya Kisaki, pp. 310-12.

\section{Andrew Cohen Memorial Fund}

FRIENDS and admirers of the late Sir Andrew Cohen in many countries are sponsoring a Memorial Fund in recognition of his great services to Africa. As he recently devoted much of his energy to encouraging the development of administrative capacity in the new African states, it is proposed to use the Fund to enable young civil servants from African Commonwealth countries to spend some time in other African countries studying the ways in which problems of government, similar to those which they themselves face, are being dealt with elsewhere in Africa. It is hoped that the Commonwealth Foundation, established by Commonwealth Heads of Government in 1965, will administer the fellowships that will be provided by the Fund. All those who share in the appreciation of the work of Sir Andrew Cohen as one of the great civil servants who contributed so much to advancement in many African countries are invited to send contributions to the Fund, c/o Brian McDona, Eșq., C.B.E., Royal African Society, i 8 Northumberland Avenue, London, W.C. 2. 